\title{
Lendák-Kabók, Karolina, ed. 2020: Üvegplafon? Vajdasági magyar (értelmiségi) női perspektivák. ['Glass Ceiling? Vojvodina Hungarian (Intellectual) Women's Perspectives']. Újvidék: Forum. 374 pp.
}

\section{Reviewed by Agatha Schwartz, University of Ottawa, Canada agathas@uottawa.ca}

As stated by the editor of the present volume, Karolina Lendák-Kabók, she took her inspiration to embark on this fascinating project from three fairly recent publications on Hungarian women and Hungarian identity in Vojvodina, a province within present-day Serbia. These are: Vajdasági magyar nök élettörténetei ['Life Stories of Vojvodina Hungarian Women'], edited by Svenka Savić and Veronika Mitro (Újvidék: Futura, 2006); Profesorke Univerziteta u Novom Sadu: životne priče ['Women Professors at the University of Novi Sad: Life Stories'], edited by Svenka Savić (Novi Sad: Futura, 2015); and Ki vagy te, vajdasági magyar? - Írások az identitásról és annak hiányáról ['Who Are You, Vojvodina Hungarian? - Essays on Identity and Its Lack'], edited by Márk Losoncz (Újvidék: Forum, 2017). Lendák-Kabók, an assistant professor at the University of Novi Sad Faculty of Philosophy, merged her interest in the life narratives of (younger) Vojvodina Hungarian intellectual women and the complex question of Vojvodina Hungarian identity by applying methodologies of oral history and using an intersectional approach to scrutinize how ethnicity, gender, national and linguistic belonging, education, work, motherhood and family are experienced and reflected upon in the texts that she collected in 2018 and 2019.

The authors of the twenty-four contributions (one of whom is the editor herself) are all highly educated young professional women (academics, artists, actors, cultural workers, and politicians) who were born in the 1980s. This decade led up to the both dramatic and traumatic events of the 1990s marked by the wars that brutally tore apart the multiethnic Socialist Federal Republic of Yugoslavia. For the Vojvodina Hungarians, this meant a significant blow to their previously well-established position of a minority that, like other ethnic minorities in Tito's Yugoslavia, had enjoyed protection, rights and social status. Although these have not altogether vanished since the 1990s, they have certainly significantly diminished. These drastic changes were paralleled by the rapidly shifting borders of the country that would eventually be reduced to Serbia, with Vojvodina, whose earlier autonomy was essentially taken away by a nationalist Serbian political leadership, as its northernmost province. One only has to imagine the impact of such political changes and the resulting social trauma in the life of a young person born in the 1980s who would have changed citizenship every few years while living at the same address.

The narratives of the young Vojvodina Hungarian women recently collected by LendákKabók all address the ways in which the political upheavals of the last few decades affected the authors and their families, childhood, young adulthood, subsequent careers and personal paths. It is noteworthy that most contributors come from Vojvodina communities that despite the dramatic population shifts in the region particularly since the 1990s still have a Hungarian

$($ (c) $)$ EY

ULIS D-Senk 
Schwartz, Agatha. "Lendák-Kabók, Karolina, ed. 2020: Üvegplafon? Vajdasági magyar (értelmiségi) női perspektivák. ['Glass Ceiling? Vojvodina Hungarian (Intellectual) Women’s Perspectives']. Újvidék: Forum. 374 pp.." Hungarian Cultural Studies. e-Journal of the American Hungarian Educators Association, Volume 14 (2021) DOI: 10.5195/ahea.2021.452

majority, or from towns such as Szabadka/Subotica, Zenta/Senta or Topolya/Bačka Topola, where no single ethnic group forms a clear majority. This complex situation affected not only the young women's sense of ethnic identity but also their linguistic development and cultural belonging. By far, not all Vojvodina Hungarians share the experience of growing up in an essentially unilingual environment and with the state-language (Serbo-Croat or Serbian as it is now officially called, following politically infused fake linguistic divisions of the post-Yugoslav era) remaining a foreign tongue that is acquired and used only outside the family and the community. These unilingual Vojvodina Hungarians continue to struggle with the state language in their later lives, if and when their careers take them to multilingual and largely non-Hungarian environments. Only a few contributors, who were born or grew up in Zrenjanin/Nagybecskerek and Novi Sad/Újvidék (cities with a Serbian majority), or who come from multiethnic family backgrounds, did not report facing these linguistic challenges. Most were educated in a monolingual Hungarian setting including their post-secondary education, either at the Department of Hungarian Language and Literature of Novi Sad University (Bölcsészettudományi Kar Magyar Nyelv és Irodalom Tanszéke) or in Hungary proper, often at the University of Szeged or in Budapest.

How can one define a post-Yugoslav Vojvodina Hungarian identity, and is there a distinct female Vojvodina Hungarian identity? These are the two specific questions pondered by the participants in this study. Broader questions are also explored, such as the continuation of patriarchal traditions in a still predominantly sexist society, in both its overt and covert manifestations, and the challenges faced by young women of this particular generation in building a successful career and personal life. The latter is still defined by most of them as a heterosexual relationship, preferably marriage, and motherhood. Accordingly, most of the participants juggle a demanding career and the role of wife and mother. Several question the patriarchal gender-model that is still passed down from mother to daughter and that essentially normalizes women's self-sacrifice, along with the exemption of men from housework duties. Sadly, to this day many men but also women still consider this model as "natural." Some struggle with shaking off the expectations of super-womanhood and walk the tightrope of permanent exhaustion as a consequence of their double and triple burden, while at the same time criticizing the perpetuation of gender stereotypes that in the still somewhat provincial society of Vojvodina (albeit, as pointed out by some, not as conservative as other regions in Serbia) are very slow to change.

Several contributors consider ethnic equality to be of equal importance to gender equality, with the latter in most cases being tied to the level of women's economic independence. Some voices are extremely critical, even outright negative regarding chances of success in the Vojvodina academic world and even more so in the broader Serbian one. For some, all this is linked to a dual discrimination (ethnic and gender-based), but also rooted in a more general atmosphere of envy, lack of competence and collaboration infused with political interests that split the already small local Hungarian intellectual community. Most contributors are in unison when it comes to defining Vojvodina Hungarian identity as one that sets them apart in Serbia, but also in Hungary, their alleged anyaország ['motherland']. They report not really feeling at home in Hungary, often because of exclusionary remarks they receive regarding their language use and different accent. One contributor even mentions an instance of a physical attack directed at her male Vojvodina Hungarian friends. This feeling of belonging neither-here-nor-there, of being at home in both countries yet still being treated like a foreigner in both ['egyszerre vagyok 
Schwartz, Agatha. "Lendák-Kabók, Karolina, ed. 2020: Üvegplafon? Vajdasági magyar (értelmiségi) női perspektivák. ['Glass Ceiling? Vojvodina Hungarian (Intellectual) Women's Perspectives']. Újvidék: Forum. 374 pp.." Hungarian Cultural Studies. e-Journal of the American Hungarian Educators Association, Volume 14 (2021) DOI: 10.5195/ahea.2021.452

otthon mindkét országban, mégis idegennek tartanak'] (237), can certainly be considered a consequence of revived nationalism on both sides of the border. In Serbia, this nationalism became a toxic expression of the political divisions that split up former Yugoslavia. With respect to the conflict-ridden 1990s (although there are also more recent incidents), most contributors recount experiences of ethnic discrimination and hatred they either suffered in person or witnessed in their community. While their male counterparts were often physically attacked at school (e.g., beaten or pushed down the stairs) by Serbian youth, the girls were "only" verbally abused, occasionally pushed around, or told not to speak Hungarian, by both male and female Serbs.

Among the numerous anti-Hungarian graffiti that mushroomed in the period under study and which, unfortunately, have not since then stopped popping up, one stands out for its gendering of nationalism and ethnic hatred: "Madjarice su kurve" ['Hungarian women are whores'] (140). The systematic rape and forced impregnation of thousands of Bosnian women during those most horrible 1990s serve as a not so gentle reminder about where such gendering of ethnic hatred usually leads once it reaches unbridled expression. No answer is given in this book (or in any other book on this particular topic) as to how to prevent future episodes of similar horror other than by educating the young and working toward intercultural and interethnic understanding. Maybe the old slogan of Titoist Yugoslavia, "testvériség-egység" ['brotherhood-unity'] was not such a bad idea after all, even though its implementation was obviously less than perfect given that later on things went so terribly sour.

And yet this land, where it is absurd to speak of pure ethnicities as so many different groups have been living together and intermarried for centuries (even today, despite drastic population shifts, distinguished Serbian linguist Ranko Bugarski defines the Vojvodina as one of the most multiethnic and multilingual regions of Europe), produces wonderfully strong women, as emphasized in most of the narratives. All contributors take pride in their strong female family members, mothers and grandmothers (while also giving credit to their fathers and grandfathers), who taught them how to survive in difficult conditions, how to believe in themselves and be resilient; and those with children among them hope to pass down these messages to the next generation as well. And yet the glass ceiling is one that many of them hit their head against not only as educated Vojvodina Hungarian women; it is a ceiling that forces many young talented people of all backgrounds from this both beautiful and cursed region and country to leave. For example, why must a highly qualified young person, the writer of one of the chapters, pursue research about the legacy of Austria-Hungary in the Vojvodina at Oslo University? Why would such a project not exist and be supported at the University of Novi Sad, for example?

To conclude with a quote from the book, as formulated by one of the contributors: "Szerintem nincs vajdasági magyar női identitás. Identitás van. Ahányan vagyunk, annyiféle létezik. Mert így kerek a világ" ['I do not think there is a Vojvodina Hungarian female identity. There is identity. As multiple as we are. Because this is the way of the world'] (90). As a female Vojvodina hybrid expat myself, and with the same multiethnic and multilingual roots that characterize this region and its complex history, I am probably somewhat biased when I say how enjoyable a reading this book is for the reader. Still, a Conclusion by the editor, one that would have summed up the salient points, rather than run across the narratives, would have made the book even stronger. But overall, the volume is well conceptualized and carefully edited, and I strongly believe that it will resonate with many readers, both because of the high quality of the texts assembled in it (which proves that Hungarian is very much alive and continues to be a 
Schwartz, Agatha. "Lendák-Kabók, Karolina, ed. 2020: Üvegplafon? Vajdasági magyar (értelmiségi) női perspektivák. ['Glass Ceiling? Vojvodina Hungarian (Intellectual) Women's Perspectives']. Újvidék: Forum. 374 pp.." Hungarian Cultural Studies. e-Journal of the American Hungarian Educators Association, Volume 14 (2021) DOI: $10.5195 /$ ahea.2021.452

strong identity marker for a substantial albeit dwindling number of Vojvodina people), and because the experiences relayed by the contributors will be shared by many as they contain universal messages that go beyond a local case study. 